\title{
Justice as a Principle of Law and Basis of Legal Practice
}

\author{
Valentina S. Bredneva ${ }^{1}$ \\ ${ }^{1}$ Sakhalin State University, Sakhalin region, Yuzhno-Sakhalinsk, Lenina street, 290, Russian Federation \\ Correspondence: Valentina S. Bredneva, Sakhalin State University, Sakhalin region, 693000, Yuzhno-Sakhalinsk, \\ Lenina street, 290, Russian Federation. E-mail: v-bredneva@mail.ru
}

\author{
Received: August 23, 2014 Accepted: September 7, 2014 Online Published: November 27, 2014 \\ doi:10.5539/ass.v10n24p224 URL: http://dx.doi.org/10.5539/ass.v10n24p224
}

\begin{abstract}
The principle of justice reflects the essence of law and compromise between the state and the citizen. The purpose of the present research is to determine the content and status of legal justice as a basis for legal practice. Manipulation of evaluative concepts is very complex within legal practice as it appeals to the conscience, search the boundaries of just and unjust. The rapid development of scientific knowledge changes the traditional interpretation of the rights and obligations, people's legal consciousness, ways to implement the usual rights and obligations.
\end{abstract}

Keywords: legal practice, justice, law, principle of law, legal consciousness, legal culture

\section{Introduction}

In the scientific literature, they have been arguing about justice as a legal category for more than twenty years, but there is no any unifying vision, it has not holistic, unambiguous definition (Semigin, 2008; Vlasova, 2003; Lunina, 1997). Even more complex question is the relationship between the justice and the law (Law and Justice, 2007; Law. Acceleration. Justice, 1989).

Definition dictionaries give different interpretations of "justice": as "the distribution of good and evil", "truth in action", "correspondence between the role of the person in society and his social and legal position, the proportionality between the act and reward, between the honored behavior and reward", the justice is equated impartiality (Russian Definition Dictionary, 2008; Russian Definition Dictionary, 2009).

Such a philosophical category exists in many languages of the world-in French "justice" is "une équité, in English "justice". In Polish, Spanish, German, Chinese, and many other languages, there is also a similar semantic unit. This suggests that justice as an element of justice consciousness, the legal fact, a culture element has an international format, and occupies an important place in the life of society.

Many popular expressions and aphorisms have been created on the essence of justice, many philosophers and thinkers speculated about it, e.g.: "To teach people to love justice, we need to show them the results of injustice" (Smith, 1880); "Justice is not a part of virtue, but all virtue, and its opposed-the injustice-are not part of the depravity, but depravity in general" (Aristotle, 1978); "For most people love of justice is just the fear of being subjected to injustice" (De La Rochefoucauld, 1993); "The concept of justice is subject to fashion as well as women's jewelry" (Pascal, B.).

One can agree with the statement of Cicero, that "there are two first principles of justice: harm no man and benefit society." Human rights, recognized and protected by the state, are based on the same postulates, not accidentally it became an axiom that "one person's rights end when another's rights begin."

In foreign literature, the theory of justice is considered (Brian, 1989; Rawls, 2001; Card, 2000). John Rawls wrote: "The rules of background institutions required by the two principles of justice (including the difference principle) are designed to achieve the aims and purposes of fair social cooperation over time" (Rawls, 2001). In Canada, it is recognized that "Laws are also aimed at ensuring fairness" (Canada's system of justice, 2005).

\section{Materials and Methods}

As part of this research, the author conducted a sociological study on the legal consciousness, justice, human rights.

The survey was conducted by the author with the assistance of Sakhalin State University Sociological 
Laboratory in 2008. With an inaccuracy of 5\%, only 380 respondents, of which 150 are students, 140 are specialists with secondary vocational education, and 90 are specialists with higher education.

Sakhalin respondents were asked the following question: "What is firstly necessary to be taken for every member of society respects absolutely all laws?"

$34 \%$ of Sakhalin respondents believe that "this cannot be achieved at all", $20 \%$ of them offer "to improve the quality and clarity of laws", $10 \%$-"to toughen penalties for offenses." $36 \%$ of respondents believe that "it is necessary to provide a mechanism for the implementation of laws that all human rights are guaranteed, and make impossible to avoid legal liability."

At the same time, $36 \%$ of Sakhalin respondents believe that their rights are "systematically violated." Only $7 \%$ pointed out that their rights have been never violated. 57\% of Sakhalin respondents chose the answer "rarely." Other researchers studying the citizens' attitude to various legal phenomena have the similar results (Michailovskaya, 1995; Ryabce, 2005).

We used scientific and special methods in this research.

\section{Results}

The principle of justice as a principle of law expresses the essence of general social rights and the search for a compromise between the parties of the legal relations between the state and the citizen (Malko, 2005). The principle of justice is directly enshrined in the Criminal Code (Article. 6 of the Criminal Code), but not enshrined in the Land Code, but it does not mean that when considering land disputes, enforcer shall make unjust decisions, the diversity of principles and conditions need to be considered (Criminal Code of the Russian Federation, 2009; Land Code of the Russian Federation, 2008).

Any judgment is evaluated by citizens in terms of justice or injustice that is why "justice" has a practical purpose in life of the society and the individual.

What is fair or not is not always easy question. And is it true when the actors themselves are not willing to exercise their rights enshrined in and guaranteed by the state?

Thus, in particular, within the aforementioned study, Sakhalin respondents were asked: "If you were cheated when buying anything or using the services, what would you do?" Only $16 \%$ of respondents answered "I bring a claim in writing, defend my interests by all legal means, go to court." $5 \%$ consult a professional lawyer to protect their rights. The rest either do nothing $(5 \%)$ or categorically demand the observance of their rights $(21 \%)$, or trying to "resolve the issue peacefully (without trial)" (53\%).

Thus, the consumers themselves do not exercise the rights provided for by the Civil Code, the Law "On Protection of Consumers' Rights" for various reasons.

Sociological research has also shown that the majority of Sakhalin respondents has not yet emerged a clear legal directions. Maybe this is why some of the questions were answered "depending on the situation" (77\%), "depends on the severity of the crime" (65\%).

It turns out that the respondents themselves have not decided what would be their behavior in a given situation, and therefore they are not always able to determine what is definitely just, and what is not... And that is the actual problem, the boundaries of justice in real life are not clearly demarcated, and one would consider something is just, for another it may be unjust.

In this case, in addition to the category of "moral justice", "social justice", there is a "legal justice", the boundaries of which are designated by laws and other legal acts.

Most often in a real professional practice, lawyers face the discussion feature of these categories. Legal practice is a type of conscious social activity and is characterized by the active use of legal means, provided with different elements and levels of legal consciousness, aimed at achieving the result.

The lawyers' professional legal consciousness is qualitatively different from legal consciousness of other populations in scope and depth of political and legal knowledge, and skills to analyze legal problems, to solve legal problems posed by life. However, internally it can be differentiated into separate species, listed as legal consciousness of investigators, prosecutors, judges, lawyers. This species difference is determined by features of employees' role behavior within various legal services, i.e. the specificity of the official functions and stereotypes about legal reality established in this regard, and the methods and means of the activity.

\section{Discussion}

A. S. Koblikov believes that the lawyer conducting the proceedings or performing other functions operates in 
the field affecting the vital benefit of the people, faces with many collisions, has to make responsible decisions, often in complex moral situations (Koblikov, 2007).

In the foreign literature, scholars are trying to formulate rules and formulas that determine the choice of an individual based on his interests (Karni \& Safra, 2002). Also the factors influencing people's legal consciousness in a difficult situation are investigated (Oliver, 2006).

Some researchers believe that "in the process of law-making the errors, collisions are frequent. And then the spirit of the law, legal consciousness comes to the fore. The lawyer's legal consciousness is in the first place. And if this legal consciousness is in harmony with the spirit of the law and natural right, then the problem is solved, and the right continues to be associated with justice" (Gaydamakin, 2007).

Fairly agree with the statement that "the written laws still should not contain logical errors, otherwise the flow of legal collisions will disorient society" (Andreev, Berezkin, \& Kantonistov, 1998). Work in this direction is being exercised, computer-aided analysis systems of legal texts are being developed that is designed to improve the quality of regulations (Andreev, Berezkin, \& Kantonistov, 1998).

Thus, the content and the legal validity condition is also caused by the quality and efficiency of law-making activity.

Positive law rather strictly, roughly regulates social relations. However, there are many legal rules, the implementation of which in varying degrees depends on the discretion of the law enforcer, his ideas about the content and nature of the social, moral and legal justice.

Manipulation of evaluative concepts is very complex for law enforcement, because again and again it makes him contact to the conscience, seek the boundaries of just and unjust (Kashanina, 1974; Levina, 2007).

For example, Article 92 of the Family Code of the Russian Federation:

"The court may release a spouse from the obligation to maintain the other disabled spouse who is in need of assistance or limit this obligation to a certain period, both during the marriage and upon its dissolution, as follows:

- If the disability of a spouse who is in need of assistance was caused by the abuse of alcohol, drugs, or as a result of an intentional crime;

- In the case of a short marriage period;

- In the case of misconduct in the family by a spouse requesting alimony" (Family Code of the Russian Federation, 2011).

In this case, the Family Code does not open, what "a short marriage period" means, what period is exactly meant? What actions do constitute "misconduct"? Who should be considered as "in need of assistance"? What period can the court "limit this obligation"?

"Justice" is not only the "principle of law", "'the distribution of good and evil", "one of the virtues", "the key link, the foundation of legal consciousness", but also the principle of human relations. In this context, justice can be interpreted as doing things by truth, in all conscience, by right, by law.

Moral and social justice or its antipode, injustice, is refracted in the destiny of a person through his age, experience, traditions, habits, religious ideas. Social groups' interpretations on the just and unjust, rights and obligations can be fundamentally different. In particular, the child can consider as unjust a parents' ban to exercise his right of self-expression (for example, if the way of expression is uncertain and irreversible). Parents in this situation, appealing to common sense, obligations prescribed by the Family Code of the Russian Federation, deem unfair to allow a minor to take a hasty decision, which in the future may adversely affect his health or career.

Many people talk about justice, everybody wants it, but are there those who passing cross-road at a red light finds time to go to the competent authorities to ask for a just punishment?

So, we are talking about justice, when it comes to the distribution of wealth in our favor, when it comes to punishment, probably most people would prefer to avoid punishment than to accept it, even if this is just. And this is a critical facet of justice.

Fierce disputes are conducted about if justice is objective or subjective. Some argue that justice is an objective category, it is the same for everyone, and not everyone has his own justice. Is it possible?

Can naturally subjective man be entirely objective and fair? Can the person in the situation affecting him 
personally or his relatives be impartial? And does the point of view that justice is an illusion has the right to existence? Justice is somewhat like a distant ideal, the same to "constitutional state", "civil society", everyone imagines it only in general outlines, how it should look, but no one saw it...

The idea of absolute justice probably will always exist, but will there be completely impartial, objective, fair persons, capable to realize it?

In general, the concept of "justice" can occur only in the community of people who have a certain set of rules-the law, morality, the individual's ethic principles. The concept of "justice" is associated with the categories of "power", "court", "management."

Justice issues affect many spheres of social life: religion, education (Potgieter, 2011).

Ideally, the "moral", "social" and "legal justice" shall be the same. But in reality, the single individual's interpretation about right and wrong may not coincide with the idea of a society of good and bad, like other beliefs about the allowable and the forbidden may occur among law-making authorities.

Legal notions of justice of human rights and obligations, permissions, and prohibitions affect the formation of motives and attitudes of human behavior in the legal sphere of society, and an active role of the law, justice is manifested in the regulation of the individual's legal behavior. In the modern period, a new paradigm is forming, the values are redefining from the view of the just and unjust. Science and legislation of various countries face the problem of the legal evaluation and law regulatory of the results of science and technology that affect the fundamental human rights. The rapid development of scientific knowledge changes the traditional interpretation of the rights and obligations, people's legal consciousness, ways of implementation of the usual rights and obligations, the new types of legal practice are created.

Structure of legal practice is an open dynamic system, which main elements are a subject, object, objective side, subjective side, legal means, cause-and-effect relationships. The subjective side includes perceptions of the just, motives, goals, will, different legal orientations, the content of which is due to the level of justice as a whole. In the legal practice, the components of legal consciousness "turn on" and function to achieve results. The subject is a person, who carries out legal practice. The subject may have power or not to have any, may actively use the granting rights or obligations. The object is the aspect that is the aim of socio-converting, targeted actions of subjects. In the most general form, the object is public relations. The objective side is legal actions and operations, implemented specific rights and obligations.

Thus, human rights are an essential element of legal practice, complement its objective side, are the basis, foundation, contribute to the achievement of social and beneficial result.

In essential law concept, the human rights are considered to be just, essential, inalienable, arising either from the mind or from the divine will, or from the unchanging nature of man himself. Positive direction is coming to them as to the category established by the state. In the first case, the law only perpetuates existing just rights and freedoms, in the second case, it creates them. The human rights are different in nature. There are rules, which act as innate qualities, such as the right to life, the right to personal integrity. State shall consider these individual's claims and seek the ways to enforce them. But there is another group of rights, which are obtained only through the actual implementation of the legislative activity of the state (for example, the right to receive pensions, scholarships, the right to elect and to be elected.) Combining these concepts, we can make a just conclusion that the man objectively has the right to various social rights, but only their legal recognition and binding turns these rights into a reality.

Some authors call the interdisciplinary institution of "human rights" as a particular way of the legal regulation of social relations, which is aimed at conservation, protection and restoration of violated rights (Pashynskaya, 2008). It is important to emphasize that the real value of the considered category depends on its actual implementation, which is manifested not only in the fact of the recognition and enhancement of human rights, but depends on the efficiency of the rights protection and guarantee mechanism. Such social and legal mechanisms are particularly important for the awareness and understanding of the regulatory values of human rights both in scientific, professional, and mass legal consciousness.

The category of "human rights" due to its popularity has gained a lot of revisions and versions, often significantly deviated from the original ideas, lays its foundation. The human rights are sometimes identified with the concept of "freedom", for example, "Human rights are a freedom guaranteed by such rights as freedom of thought, religion and discussion, the right to choose one's place of residence, the right of free search, receiving and distribution of information, activities. ... Human rights associated with the person's freedom are anyway limited to the rights and freedoms of others, i.e., may not be exercised to their harm" 
(Political Encyclopedia, 1999). In fact, the freedom of the person is the same capabilities of the individual to choose the type of his behavior (and right), but with some special features. Providing the freedoms, the state focuses on the individual's maximum self-determination.

In an ideal model, the state is committed to minimum regulatory of the citizens' behavior, ensuring their freedoms by all non-interference both from itself, and from all other social subjects. It is this state that in jurisprudence is called as a just, social, legal one.

There are other facets of understanding of human rights, such as the human rights as a reflection of the individual's dignity, as a tool to limit the power, as a feature of "man-state" relations (Human rights and problems of identity in Russia and in the modern world, 2005).

It can be stated that the content of the human rights is affected by various factors (mental, regional, cultural), as representatives of different countries, different religions lay their particular understanding. Regional human rights aspect is important when it is necessary to understand the characteristics of legal consciousness and of law residents of one or another republic or region, because the way to the developed civil society and responsible efficient just state lays through each person's understanding of his rights.

Individual rights and freedoms are inseparable from the obligations. Undoubtedly, the rights of one end when another's rights begin. The Constitution of the Russian Federation fixes obligations (not to violate the rights and freedoms, legitimate interests of others; not to make a propaganda or campaigning inciting social, national, or religious hatred and enmity; not to harm the environment, to take care of the preservation of historical and cultural heritage, to preserve historical and cultural monuments, etc.) (Constitution of the Russian Federation, 2014).

Thus, the category of "human rights" has moral, legal, political, social, ideological, integrative features, accumulates basic democratic values and is an indicator of the society development.

Problems of determining the boundaries of life and death, the debate about cloning, the death penalty, the organ and tissue transplantation, euthanasia, gender reassignment are directly related to the most important essential human rights.

Discussions about the possibility of new generation rights are not limited by jurisprudence, the philosophers, sociologists, political scientists are also looking for a model of an ideal society. The society is rapidly approaching the time when a person tries to exercise the rights that are formally not fully secured and do not fit into the current model of legal structures.

The world community has not yet come to a common denominator and cannot respond to many ethical, legal and social issues that arise and will arise in connection with the development of science and technology. For example, in the case of cloning permission, will the copy have the rights of the original? Which family ties will be a clone with the original? And is in the future it possible to consider cloning as a means of reproduction, that is, as a reproductive technology when cloning is the only possibility to have one's own child?

Another serious issue is the contention of rights. For example, the state's right to integrity and indivisibility, the right of nation to self-determination, to secede from the state. These rights directly affect the status of the territories.

The public's right to environmental well-being and the right to engage in business activities, which in some cases is accompanied by environmental pollution (for example, associated with the production of toxic chemical substances) are also opposed.

Which rights are in such situations of a higher priority?

International law is intended to smooth out the cultural and ethical contradictions in the understanding of human rights, to develop a universal theory of justice. It is not easy to be made, given the diversity of countries, cultural and ethnic factors. The human and citizen's rights and freedoms volume and list in the state legislation varies from power of democracy, the specifics of the legal regulation, the set of legal tools, the boundaries of ideas about the just and unjust.

\section{Conclusion}

The cornerstone of "justice" is that representations of good and evil with the passage of time, from the era to the era change, and those existing rules, which were once considered moral, through the centuries can become completely immoral. In addition, the fact that one ethnic group can consider as the norm, for the other may be totally unacceptable. 
Thus, there are still some African tribes, where there is a tradition to cast witches, while the woman is declared a witch, if a family has an accident, such as death or illness of someone in the family. And this is considered just. From the standpoint of a developed society, this situation is unjust.

Those civilizations, where aggression and delinquency are common, are considered to be inadequate in terms of humanity, and their laws and regulations are considered as failing to meet basic human rights. The society where foreign people trust and help each other, and where they live without oppression and fear are evaluated positively by the international community. In fact, the overall assessment of the justice or injustice comes from the quality of implementation of the principles which have already been formed in international law, "the equality of all before the law", "rule of law", "integrity", "presumption of innocence", etc.

Thus, justice has many facets, fragmentary embodies in law, social norms, moral principles of an individual. Exercising his rights and obligations in accordance with his conscience, a sense of justice, everyone can approach a society for a little bit closer to the ideal, which is still argued, creating models of the constitutional state and civil society.

\section{References}

Andreev, A. M., Berezkin, D. V., \& Kantonistov, Y. A. (1998). Expert legal systems: myth or reality? PC World, 9, 8 .

Aristotle. (1978). Works in 4 volumes, 2, 349-532. Moscow: Thought.

Brian, B. (1989). Theories of Justice. Berkley: University of California Press, Rawls, J., 2001.

Canada's system of justice. (2005). Ottawa, Ontario: Communications Branch Department of Justice Canada, 2.

Card, C. (2000). Individual Entitlements in Justice as Fairness. In Davion, Victoria, \& C. Wolf (Eds.), The Idea of Political Liberalism (pp. 176-189). New York: Rowman and Littlefield.

Constitution of the Russian Federation. (adopted by popular vote on 12.12.1993, ed. 21.07.2014). Collection of Laws of the Russian Federation (2014), 31, 4398.

Criminal Code of the Russian Federation: Federal Law of 13.06.1996 \#63-FZ. Collection of Laws of the Russian Federation, 1996, \#25, Art. 2954. Ed. Law \#20-FZ of 13.02.2009. Collection of Laws of the Russian Federation, 2009, \#7, Art. 788.

De La Rochefoucauld, F. (1993). Memoires. Reflexions ou sentences et maximes morales. Moscow: Science. Translated by Linetskaya E.L.

Family Code of the Russian Federation. Russian Newspaper, of 27.01.1996 \#17. Ed. \#363-FZ of 30.11.2011. Retrieved December 1, 2011, from http://www.pravo.gov.ru

Gaydamakin, A. A. (2007). Ppolemical notes on the logic of the law and legal consciousness. State and law, 7 , 92-95.

Ivannikov, I. A. (2007). Law and Justice. Abstracts of scientific-theoretical conference (p. 124). Rostov-on-Don.

Karni, E., \& Safra, Z. (2002). Individual sense of justice: A utility representation. Econometrica, 1(70), 263-284. http://dx.doi.org/10.1111/1468-0262.00275

Kashanina, T. V. (1974). Evaluation concepts in Soviet law (p. 185). PhD thesis, Sverdlovsk.

Koblikov, A. S. (2007). Legal Ethics (p. 165). Moscow.

Land Code of the Russian Federation of 25.10.2001 \#136-FZ. Collection of Laws of the Russian Federation, 2001. No. 44. Art. 4147. Ed. Law \#141-FZ of 22.07.2008. Russian Newspaper of 25.07.2008 \#158.

Levina, D. N. (2007). Theoretical problems of interpretation and application of evaluative concepts (p. 216). $\mathrm{PhD}$ thesis, Nizhny Novgorod.

Lunina, N. A. (1997). Social justice and labor law (p. 131). Voronezh.

Malinova, O. Y, \& Sungurov, A. Y. (2005). Human rights and problem of identity in Russia and in the modern world (p. 272). Proceedings of the International Scientific and Practical Symposium. St. Petersburg: Norma.

Malko, A. V. (2005). Legal Science (p. 72). Moscow.

Michilovskaya, I. (1995). Individual Rights and Freedoms in the mass consciousness of the Russian population. Constitutional Law: East European Review, 1, 32-37.

Novoselov, V. I. (1989). Right. Acceleration. Justice (p. 157). Saratov. 
Oliver, C. R. (2006). Catastrophe's Impact on Leaders' Caring and Justice: Changes in Moral Reasoning. International Journal of Leadership Studies, 2(1), 80-98.

Ozhegov, S. I. (2009). In L. I. Skvortsov (Ed.), Russian Definition Dictionary (p. 1358). Moscow.

Pashynskaya, I. V. (2008). Ways to improve legal procedures to ensure the human and citizen's rights and freedoms. Legal policy and legal life, 1, 129-132.

Political Encyclopedia (Vol. 2). (1999). Scientific Project Head G. Yu. Semigin. Moscow: Thought Press.

Potgieter, F. J. (2011). Morality as the substructure of social justice: Religion in. South African Journal of Education, 31, 394-406.

Rawls, J. (2001). Justice as Fairness (p. 52). London: The Belknap press of Harvard University Press.

Ryabcev, R. A. (2005). Current legal reform in Russia and legal consciousness: Theoretical and legal problems of changing in citizens' legal consciousness (p. 51). $\mathrm{PhD}$ thesis, Moscow.

Semigin, G. Y. (2008). Social justice and law (p. 197). Moscow.

Smith, A. (1880). Essays philosophical and literary (p. 473). London: Ward, Lock \& Co.

Ushakov, D. N. (2008). Russian Definition Dictionary (p. 1054). Moscow.

Vlasov, M. V. (2003). Title and social justice: Theoretical and historical research (p. 22). Synopsis of a PhD thesis, Moscow.

\section{Copyrights}

Copyright for this article is retained by the author(s), with first publication rights granted to the journal.

This is an open-access article distributed under the terms and conditions of the Creative Commons Attribution license (http://creativecommons.org/licenses/by/3.0/). 